\title{
Disability Evaluation of Postapoplectic Hemiplegic Patients
}

\author{
by \\ Ryuichi Morizono, M. D.
}

from

The 1st Dept. of Internal Med., Kagoshima Univ. Medical School

\begin{abstract}
The evaluation of patients' disability is one of the most important problems in the process of medical rehabilitation. The disability evaluation should necessarily be a comprehensive one that considers psychological, social and vocational as well as medical factors. It is also desirable that the evaluation method by which we assess patients' disability and presuppose the rehabilitation potential is as simple as possible, regardless of so many factors to be evaluated.

As regards neurological, orthopedic, psychiatric and psychological, and socioeconomic factors, I selected respectively 4 items which would inhibit restoration of the patient. Disability score was shown by the total score of these 16 items. The reliability of the results of this method was examined by comparing them with those of $6 \mathrm{ADL}$ groups which were determined by ambulation and selfcare abilities. The results obtained can be summarized as follows :

1) The results of rehabilitative treatment in 106 patients were examined by comparing one's ADL group on admission and on discharge. A good many patients showed marked recovery, but no improvement was seen in 11 cases.

2) There was shown a high degree of correlation between disability score on admission and ADL groups on discharge. Thus it was assumed that disability score obtained by the method presented here can be a useful index for predicting the state of ADL on discharge.

3) The result of comparison of disability score on admission and duration of disease before admission didn't show any significant change. One of the important reasons, of this result was that this scoring method of disability lacked the detailed analysis of disuse syndrome.

4) The results of comparison according to age-groups less than 59 years and more than 60 years of both the disability score on admission and ADL groups on discharge were respectively accepted as significant.

5) The results of comparison according to the presence or non-presence of complication of both the disability score on admission and ADL groups on discharge were respectively not accepted as significant. This naturally shows that the factor which matters is the severity and kinds of complication rather than its presence or non-presence.
\end{abstract}




\title{
研究と報告
}

\section{脳卒中後片麻舫患者の Disability Evaluation}

\author{
森 園 隆 一*
}

\section{はじめに}

リハビリテーションが医療概念として臨床医学の一部 門を占め，それに対する社会的関心もしだいに高まりつ つある今日，臨床医は単に患者の身体面の事項に精通す るのみならず，パラメジカルスタッフの協力のもとに， 患者の心理的, 社会的, 職業的因子を孔分析・収集して より包括的なアプローチをとる必要があることが認識さ れるようになった，脳卒中後麻疩にかぎらず，身体障害 者のリハビリテーションを論ずるとき，その身体的機能 障害 (physical impairment) のみを考慮しては, 思わ ぬ失敗に遭遇することがある。 Ruilmann ${ }^{1}$ によると， 高齢の身体障害者では, 高いリハビリテーション・ポテ ンシァルを利用しえない要因として，多くは精神障害を も含めて, 社会・経済的問題があることが指摘されてい る. 以上のよらな観点からみるとき，Disability Evaluation とは患者を身体的一心理的一社会的な統一体と してみた全体的評価であることが肝心であるといえる。

著者は脳卒中後片麻㿎患者の Disability Evaluation の方法として, 神経学的, 整形外科的, 精神医学 - 心理 学的, 社会・経済的の 4 要素について, 回復阻害的に作 用していると考えられる因子をそれぞれ 4 項目ずつ之り あげ,これら該当する項目を合計して disability score とした.この得点法が Disability Evaluation の方法之 していかなる意味があるかを症例ををじえて検討した。

\section{I. disability score による評価法}

患者の欠けた能力を包括的に把握するためには, 評価 要素が広いだけに, 評価項目としてはなるだけ簡便な方 法をとるのが評価成績の総合的評価という点からも用い やすい.この意味で, 表1亿示すように神経学的, 整形 外科的, 精神医学・心理学的, 社会・経済的の 4 要素に つき,評価すべき阻害因子をそれぞれ4 項目ずつ設定し，

\footnotetext{
$*$ 鹿児島大学医学部第一内科 (主任: 金久卓也教授)
}

これら該当項目を合計した点数を disability score とし た．したがって，すべての項目が該当した場合は， disability score が 16 点となる.

ついでながら, ADL 改善の指標として, 表 2 亿示 したように 6 群から成る ADL 判定基準を設定した。こ の ADL 群分類の特徴は歩行能力と self-care の能力と を対応させて段階つ汁たもので，1つの ADL 群の規定 事項が 1 つでる条件に合わない場合は，元秃より1つ下 位の ADL 群に属するように判定した。

\section{II. 評 価成績}

評価対象は昭和 38 年 4 月から昭和 43 年 3 月までに鹿 児島大学霧島分院に入院した脳卒中後片麻㾝患者で, 入 院時の ADL 判定基準がすでにA群に到達していた患者 を除外した 106 名である.患者の麻疩側就よび性別年齢 分布は表 3 に示した. disability score は入院 1 カ月以 内の検査成績おょび観察結果のカルテ記載事項より判定 して求めた.

評価成績についてみると，まず図1は 4 評価要素の各 項目についての例数をパーセントで示したものである. その内訳は，

神経学的要素:

I. 75 例 $70.7 \%$ (視床痛 4 例)

II. 34 例 $32.0 \%$ (弛緩性の持続 7 例)

III. 7 例 $6.6 \%$ (失調 3 例, 振戦 3 例, アテトーゼ 1 例)

IV. 11 例 $10.3 \%$ （屎尿失禁 4 例, 尿失禁 5 例, 褯創 2 例)

整形外科的要素 :

I. 38 例 $35.8 \%$

III. 29 例 $27.3 \%$

III. 29 例 $27.3 \%$ (肩関節亜脱臼 27 例, 大腿頸部骨折 1例, 大腿骨骨幹部骨折 1 例)

IV. 32 例 $30.1 \%$ (患側が健側より骨萎縮著明 14 例, 骨化性筋炎 1 例) 


\section{Neurological factors}

I. Sensory disturbance (hyperpathia).

II. Muscular hypertonia, hyperactive deep tendon reflexes, or continuous flaccidity.

III. Ataxia or involuntary movement (tremor, athetosis, etc.)

IV. Decubitus, or urinary and rectal incontinence.

\section{Orthopedic factors}

I . Severe pain of limbs and joints.

II. Contracture or deformity of joints.

III. Subluxation of shoulder joint or fracture of limbs.

IV. Atrophic or osteoporotic bones on roentgenogram.

\section{Psychiatric and psychological factors}

I . Poor motivation and marked dependency.

II. No adaptation because of emotional disturbance or anxiety reaction.

III. Emotional incontinence, hypochondriacal tendency or personality change.

IV. Delusive-depressive reaction, abnormal behavior, disorientation or intellectual deteriolation.

\section{Socio-economic factors}

I . No appreciation and co-operation of patient's family.

II. Undesirable environment as regards patient's occupation and family.

III. Lower social status and academic career.

IV. Poor financial background of patient's family.

\section{表 2 ADL Groups by Criteria for Ambulation and Self-care Ability}

A : Independent in walking and self-care.

B : Walking with a cane and partially dependent in bathing, but independent in other self-care.

$\mathrm{C}$ : Walking by assistance and dependent in bathing, partially dependent in dressing and going to toilet, but independent in feeding and grooming.

D : Transferring with wheel chair by assistance and independent in feeding and grooming, but completely dependent in other self-care.

E : Sitting on bed and partially dependent in feeding and grooming, but completely dependent in other self-care.

$F$ : Confined to bed and completely dependent in all self-care.

Note : If activities of the patient do not correspond to an article in respective ADL group, the patients group belongs to one degree less than that mentioned.

\section{精神医学・心理学的要素 :}

I. 42 例 $39.6 \%$

II. 56 例 $52.8 \%$

III. 34 例 $32.0 \%$ (情動失禁 16 例, 心気的傾向 12 例, 性格変化 20 例)

IV. 17 例 $16.1 \%$ (妄想 6 例, 抑 5 つ反応 7 例, 行動 異常 3 例, 失見当識 9 例, 知能荒廃 2 例)

\section{社会・経済的要素 :}

I. 26 例 $25.4 \%$

II. 14 例 $13.2 \%$

III. 25 例 $23.5 \%$

IV. 17 例 $16.0 \%$

である。

次に入院治療による効果を，入院時と退院時の $\mathrm{ADL}$ 判定基準による $6 \mathrm{ADL}$ 群の例数で比較した(表 4 ). 大 院時にはB群以下であったものが，退院時には完全独立 31 例となり治療効果がみられたが，不変 11 例を数え， このらち F群の 4 例は入院当初からリハビリテーション
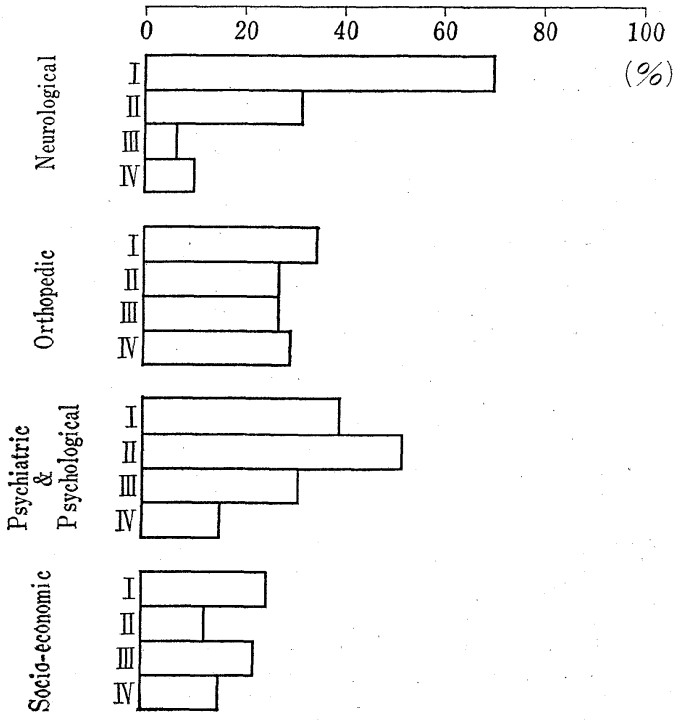

図 1 Percentage of 'Patients' Number according to 4 Evaluation Factors 
表 3 Age and Sex Distribution of Hemiplegic Patients and Affected Side

\begin{tabular}{|c|c|c|c|c|c|c|c|}
\hline & \multicolumn{6}{|c|}{ Age } & \multirow{2}{*}{ Total } \\
\hline & -30 & $31-40$ & $41-50$ & $51-60$ & $61-70$ & $71-$ & \\
\hline L-Hemiplegia $\left\{\begin{array}{l}\text { Male } \\
\text { Female }\end{array}\right.$ & & $\begin{array}{l}4 \\
1\end{array}$ & $\begin{array}{l}5 \\
1\end{array}$ & $\begin{array}{r}11 \\
7\end{array}$ & $\begin{array}{l}12 \\
10\end{array}$ & $\begin{array}{l}6 \\
5\end{array}$ & $\begin{array}{l}38 \\
24\end{array}$ \\
\hline R-Hemiplegia $\left\{\begin{array}{l}\text { Male } \\
\text { Female }\end{array}\right.$ & 1 & $\begin{array}{l}1 \\
1\end{array}$ & $\begin{array}{l}4 \\
2\end{array}$ & $\begin{array}{l}9 \\
3\end{array}$ & $\begin{array}{l}9 \\
6\end{array}$ & $\begin{array}{l}4 \\
4\end{array}$ & $\begin{array}{l}28 \\
16\end{array}$ \\
\hline Total & 1 & 7 & 12 & 30 & 37 & 19 & 106 \\
\hline
\end{tabular}

表 4 Number of Patients by 6 ADL Groups on Admission and Discharge

\begin{tabular}{|c|c|c|c|c|c|c|c|c|c|}
\hline \multirow{2}{*}{ On Discharge } & & \multicolumn{8}{|c|}{ On Admission } \\
\hline & & A & B & C & $\mathrm{D}$ & $E$ & $\mathrm{~F}$ & & tal \\
\hline Completely Independent & $\mathrm{A}$ & & 5 & 17 & 8 & & 1 & 31 & 31 \\
\hline Partially Dependent & $\stackrel{\mathrm{B}}{\mathrm{C}}$ & & 4 & $\begin{array}{l}9 \\
3\end{array}$ & $\begin{array}{l}4 \\
2\end{array}$ & $\begin{array}{r}13 \\
6\end{array}$ & $\begin{array}{l}9 \\
3\end{array}$ & $\begin{array}{l}39 \\
14\end{array}$ & 53 \\
\hline Slightly Independent & $\begin{array}{l}\mathrm{D} \\
\mathrm{E}\end{array}$ & & & & & 4 & $\begin{array}{r}13 \\
1\end{array}$ & $\begin{array}{r}17 \\
1\end{array}$ & 18 \\
\hline Completely Dependent & $\mathrm{F}$ & & & & & & 4 & 4 & 4 \\
\hline Total & & & 9 & 29 & 14 & 23 & 31 & & 6 \\
\hline
\end{tabular}

表 5 Correlation between Number of Patients by ADL Groups on Discharge and Disability Score on Admission

\begin{tabular}{lrrrrr}
\hline & \multicolumn{5}{c}{ Score } \\
\cline { 2 - 6 } & 0 & $1-4$ & $5-8$ & $9-12$ & $13-16$ \\
\hline A & 4 & 22 & 5 & & \\
B & 1 & 24 & 14 & & \\
C & & 2 & 9 & 3 & \\
D & & 2 & 6 & 8 & 1 \\
E & & & & 1 & \\
F & & & 2 & 2 & \\
\hline
\end{tabular}

$\mathrm{r}=0.771$

・ポテンシァルがなかったといえる.

それでは, disability score が Disability Evaluation として $\mathrm{ADL}$ 改善のめやすとなりらるかを，入院時の disability score と退院時の ADL 群との相関に求めた (表 5 ). ADL 下位の群では disability score も高く, 両者に高い相関関係がみられた。

次に disability score が発病経過と関連があるかどう か，すなわち包括的にとらえた阻害因子は各要素とも発 病経過の影響による因子としていか汇ど関与しているか を検討するため, 発病経過を 3 力月以内, 6 力月以内,

1 年以内, 1 年以上の 4 群の症例に分けて disability score と比較した（表 6). それによると，発病経過の 短いものは disability score も低い傾向がみられたが， 推計学的には有意でなかった。

次に年齢因子が入院時の disability score および退院
表 6 Comparison of Number of Patients by Disability Score on Admission and Duration of Disease Condition before Admission

\begin{tabular}{|c|c|c|c|c|c|c|}
\hline \multirow{2}{*}{ Duration } & \multicolumn{5}{|c|}{ Score } & \multirow{2}{*}{ Total } \\
\hline & 0 & $1-4$ & $5-8$ & $9-12$ & $13-16$ & \\
\hline-3 Months & 5 & 22 & 13 & 5 & & 45 \\
\hline-6 Months & & 12 & 6 & 5 & & 23 \\
\hline -1 Year & & 12 & 11 & 4 & & 27 \\
\hline 1 Year- & & 4 & 6 & & 1 & 11 \\
\hline
\end{tabular}

時の ADL 改善に影響があるかる比較した. 年齡群59歳 以下と 60 歳以上に分けて比較すると（表 7 ), 両者之も 推計学的に $1 \%$ の水準で有意の差がみられ，高齢者の disability score は高く, 退院時も低い ADL 群に属し ていることを示している。

ところで，ADL の改善に影響を及ぼす諸因子を考え るとき, 内科的合併症の存在を見のがすわけにはゆかな い。ちなみに，脳卒中後片麻痺患者 106 例中，合併症を 有するものは 57 例で, その内訳は表 8 に示すように, 高 血圧症, 冠硬化症, 不整脈（上室性 - 心室性期外収縮, 脚ブロック，心房細動）等, 動脈硬化に基づく疾患が多 数を占めている。をた同時に 2 合併症以上を有する患者 が 26 例いた。それではこれら合併症の有無により，入 院時の disability score 和よび退院時の ADL 群に差 異があるかを比較すると(表9), 両者とも合併症の有無 による差は推計学的に有意でなかった。これらの要因に 
表 7 Comparison of Number of Patients by Disability Score on Admission and ADL Groups on Discharge according to Age-Groups

\begin{tabular}{lcc}
\hline Score & -59 Ages & 60 Ages- \\
\hline 0 & 2 & 3 \\
$1-4$ & 33 & 17 \\
$5-8$ & 9 & 27 \\
$9-12$ & 3 & 11 \\
$13-16$ & & 1 \\
Total & 47 & 59 \\
\hline
\end{tabular}

\begin{tabular}{ccc}
\hline ADL & -59 Ages & 60 Ages- \\
\hline A & 24 & 7 \\
B & 18 & 21 \\
C & 1 & 13 \\
D & 4 & 13 \\
E & & 1 \\
F & & 4 \\
Total & 47 & 59 \\
\hline $\mathrm{P}<0.01$ & &
\end{tabular}

表 9 Comparison of Number of Patients by Disability Score on Admission and ADL Group on Discharge according to Presence of Complication

\begin{tabular}{lcc}
\hline Score & $\begin{array}{c}\text { Complication } \\
(-)\end{array}$ & $\begin{array}{c}\text { Complication } \\
(+)\end{array}$ \\
\hline 0 & 3 & 2 \\
$1-4$ & 28 & 22 \\
$5-8$ & 14 & 22 \\
$9-12$ & 4 & 10 \\
$13-16$ & & 1 \\
Total & 49 & 57 \\
\hline
\end{tabular}

$0.30>\mathrm{P}>0.20$

ついては考案で述べることにして，実際の 2 症例を示し てみたい。

\section{III. 症 例}

ここに述べる 2 症例はいずれも高齢者で, 麻㾇の程度 も同じ左片麻疸患者であるが，合併症は異なる．

症例 176 歳, 男性, 脳血栓後左片麻痺.

内科的合併症：不整脈（上室性期外収縮）および気管 支拡張症. 発病後 6 力月経過して入院, 入院時の disability score は 7 点で, ADL はD 群に属していた. 合 併症を考慮して運動療法には慎重を期したが，いざ実施 してみると, 高齢の割に意欲が高く, 訓練に熱中し, 自 覚的に動悸があるにもかかわらず苦痛を訴光なかった。 これを客観的な検査でとらえてみると，まず安静時の血 圧・脈搏の日中変動（図 2-A）では, 脈は徐脈で血圧の 動摇も著明でない。次に, 臥位から歩行までの動作中, テレメーターにより呼吸曲線, 心電図を記録してみると

(図 2-B), 呼吸数は, 増加しても整曲線であるのに対 して, 心電図では脈搏の増加とともに上室性期外收縮も 増加し，歩行動作が負担であることを示している．約 5 カ月後の退院時には ADL るB群にまで達した。

症例 269 歳, 男性, 脳出血後左片麻疩.

内科的合併症：本態性高血圧症. disability score : 12 点. 発病後 8 カ月経過して入院したが, 食事・洗面な

\begin{tabular}{ccc}
\hline ADL & $\begin{array}{c}\text { Complication } \\
(-)\end{array}$ & $\begin{array}{c}\text { Complication } \\
(+)\end{array}$ \\
\hline A & 19 & 12 \\
B & 19 & 20 \\
C & 5 & 9 \\
D & 6 & 11 \\
E & & 1 \\
F & & 4 \\
Total & 49 & 57 \\
\hline
\end{tabular}

$0.20>\mathrm{P}>0.10$

表 8 Complications and their Numbers

\begin{tabular}{lc}
\hline \multicolumn{1}{c}{ Complication } & Case \\
\hline Hypertension & 31 \\
Coronary arteriosclerosis & 18 \\
Cardiac arrhythmias & 16 \\
(Auricular fibrillation) & $(6)$ \\
Diabetes mellitus & 7 \\
Valvular cardiac disease & 4 \\
Rheumatoid arthritis & 3 \\
Nephrosclerosis & 3 \\
Bronchial asthma & 2 \\
Acute hepatitis & 1 \\
Myocardial infarction & 1 \\
Bronchiectasis & 1 \\
Gout & 1 \\
Banti's syndrome & 1 \\
\hline
\end{tabular}

ぞいっさい妻の介助を受けているため ADL はF 群に属 していた. 入院 2 カ月後には高血圧もコントロールされ て杖歩行の段階にまできたが，歩行時の不安感が著しく 呼吸促迫がみられた。これを客観的に検查でとらえてみ ると, まず安静時の血圧・脈搏の日中変動（図 3-A) は 血圧・脈搏とも動摇が著しく, 不安定性が示されてい る. 次に各動作中のテレメーターによる呼吸曲線, 心電 図をみると(図 3-B), 呼吸曲線は坐位より歩行に移行 するに伴って呼吸数の増加とともに不整が著しくなって いる. 心電図では脈搏の増加をみるも，有意の異常所見 


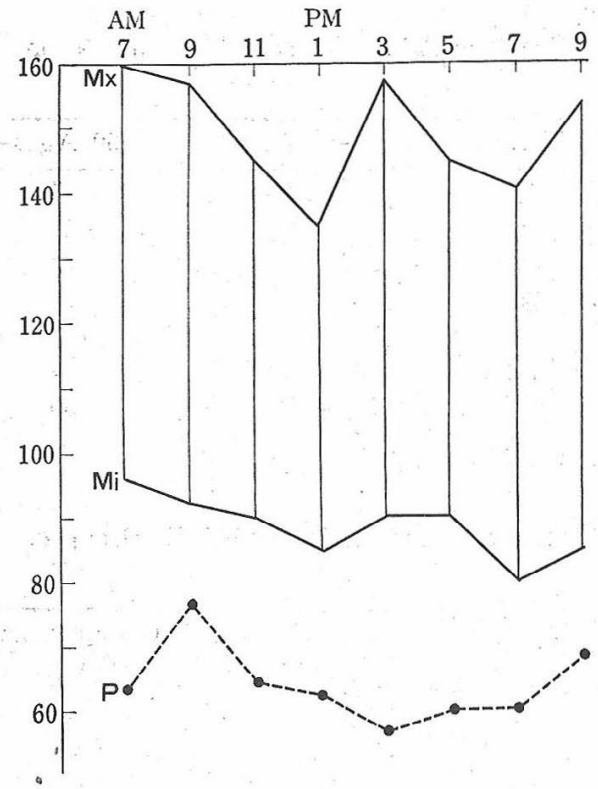

A

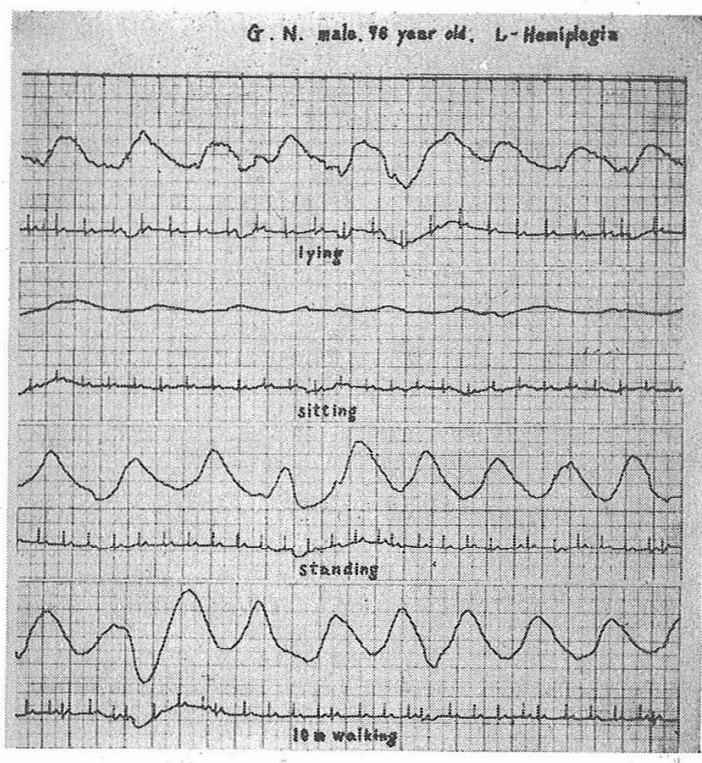

$\mathbf{B}$

図 2 Diurnal Change of Blood Pressure and Pulse Rate and Change of Respiratory Curve and ECG on Various Position by Telemetering

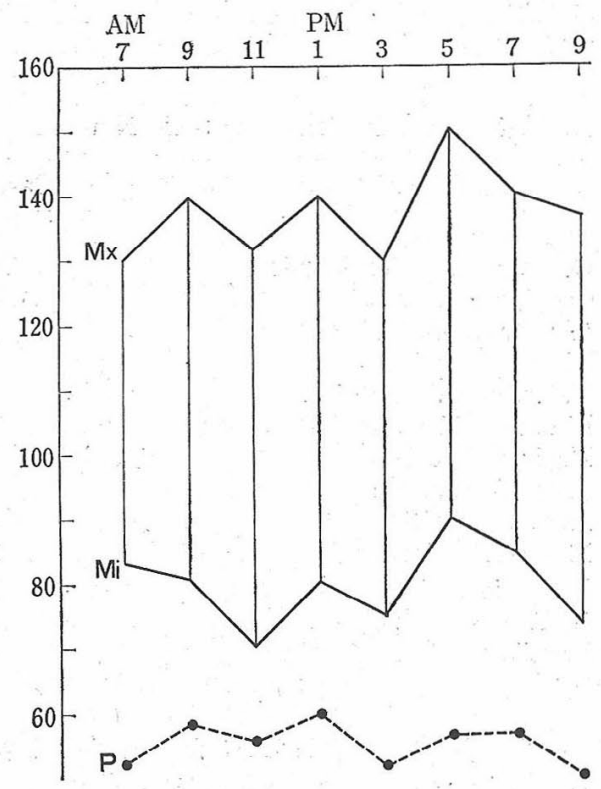

A

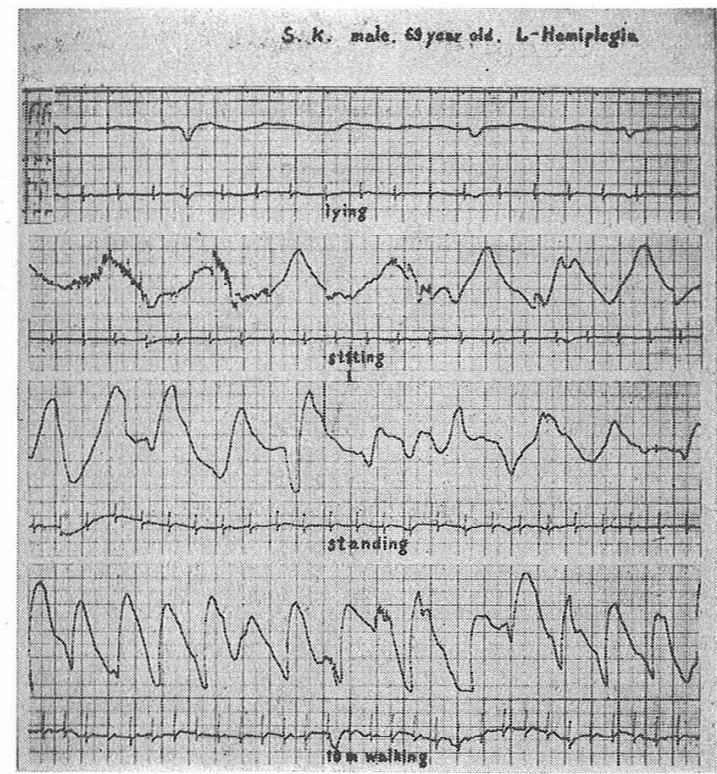

$\mathrm{B}$

図 3 Diurnal Change of Blood Pressure and Pulse Rate and Change of Respiratory Curve and ECG on Various Position by Telemetering

はみられず; disability score も精神医学・心理学的要 素の項目が高いここからる，心因性の要素が強いといえ る. 事実, 入院してからも妻に対する依存性惊不変で, 杖歩行可能でありながらも，ADL では食事・洗面動作 以外の self-care はすへてて介助され；結局はD群にとど
まって退院した。

\section{IV. 考 案}

：リハビリテーションの第 1 段階が患者の評価にはじま ることは論をなたない:とかし，この評価の目的は入院 
の適否，治療プログラムの編成，治療目標の設定，就職 の時期決定など，一連の治療過程に必要な資料を提供し 同時にリハビリテーション・ポテンシァルを推知するこ とにある。このような評価方法は Disability Evaluation が発表されてきた. Nagi²) によると，Disability Evaluation とは個人が沶かれた社会環境下で果たす社会的 役割を遂行しうる機能的水準の評価であり，一方リハビ リテーション・ポテンシァルとは個人がある社会環境下 で到達しらる機能的水準の予後的評価を意味していると 述べている。したがって， Disability Evaluation に際 しては，個人因および環境因双方にわたる包括的なアプ ローチが不可欠であるといえる。しかながら，全体的 評価法といっても臨床医がとくに関心をもつのは，身体 面である. 特に機能的側面に関しては種々の検查法が確 立されて㧺り, 運動障害の病症度, 病型の分類に为応用 されているが，これらは個別的評価法といえる3)。

ところでこれまでの全体的評価法をらりか元ってみて も, Disability Evaluation が多方面にわたる要素を評 価する以上，評価項目を多数もらけて詳細を極めること は，障害度を一見して把握しようとする点からも好まし くない.このため,どちらかといらと簡便な方法が用いら れてきた。1957年，Moskowitz ら゙)により発表された PULSES profil 法は, 身体機能, 上肢機能, 下肢機能, 感覚機能, 排泄機能, 精神機能の 6 要素につき, 障害の 程度を 4 段階に分けて，1から4 なでの数字で表示する 方法である.一見して各要素の障害度を把握できるが, 詳 細な点に関しては不明膫である。この点を考慮して作成 されたのが Sokolow ら (1958 年) $)^{5}$ の 80 欄 12 項目か らなる評価法であるが, IBM system によるるので, ど こでも採用できるものではない。簡便ではあるが評価項 目をより多くして実用性を高める目的で, Kaplan ら $(1960 \text { 年 })^{6)}$ は筋骨格運動系, 刺激感受系, オリエンテ ーション，その他，の 4 要素についてそれぞれ多数の評 価項目を設定し，表示形式として十，0，一の3 段階か ら成る relative numerical value を用いて簡潔に表現 する方法を考案した．さらに数量的にとらえる方法とし ては, Sokolow ら (1962 年 $)^{7)}$ が内科系, 筋骨格系, 特殊 感覚系, 神経系, 環境因系の 5 系統に扮の和の判定基準 を設定して点数で表わし，最後にすべてを乗じて，\% Disability として全体像をとらえている. 実態調查とし ては, 横山 ${ }^{8)}$ が在宅脳卒中後遺症患者を総合的化調查し ている.

以上の全体的評価法をみても，患者の能力を障害して いると考えられる因子をいかほど取り上げ，いかなる判 定基準で評価するかは,リハビリテーションの過程が純 医学的のものから職業的リハビリテーションに至るまで
の広い範囲にわたっているだけに，一概には規定されえ ない.しかし,評価要素のうち特に重要なのは機能的障害 (functional disability) であり, 麻疩の程度が機能回復 を左右する大きな因子之いえる，それゆえ，この種の検 查として Daniels の徒手筋力検查法等が広く応用され ている.一方, 機能的障害を ADL の改善といら面から 大きな比重を占めている上肢関して考えてみると，麻 盘側上肢の回復は発病後少なく之も 6 力月以内に決定さ

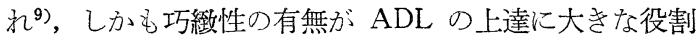
を果たしている10)11)。ざには, 麻疩側上肢の障害度と は別に，健側上肢をいか注ど参加利用するかによっても 大きな開きが生ずる。この残存機能をいかほど利用する かは患者の意欲の問題であり, 心理的因子をも含めて種 々の要素の評価によって ADL 能力をも決定されるとい える.そこで,全体的評価法といらならば,患者の各筋の 麻疩の程度も他の要素と一括して標準化することが妥当 性があるといえるが，これはきわめて困難である。ここ に, 簡便で, しかも包括的にとら去ようする Disability Evaluation の確立の困難性がある. しかし要は, 患者 の治療効果を, あるいは予後を, 判定しうる因子に妥当 性があるが゙うか，適度な尺度の判定基準を設定してい るかといらことである。この意味で, 著者は試みに Disability Evaluation の評価要素として神経学的, 整形 外科的, 精神医学・ 心理学的, 社会・経済的の 4 要素を 取り上げ, 各要素から, 回復汇対する阻害因子をそれぞ 礼 4 項目ずつ抽出設定してみ心。この阻害因子は, 疾病 の重症度から生ずる結果的因子でもあり, 将来に対して は予後的因子之当いえる。

これら入院時にお活る該当項目の合計を disability score として, 退院時の ADL 群と比較すると, 高い相 関関係がみられた。これは, disability scoreが ADL 改 善のめやすとなっても, 評価項目の妥当性を示している ものではない，脳卒中後麻痷では，高齢者で発病経過の 長い患者は回復が悪いといわれている。この点を, disability score と比較した成績（表 6，7）では，年齢因 子々の比較に有意差を認めたのに対して, 発病経過に よる比較で注有意差を認めなかった。これは評価項目と しての阻害因子に加龄現象と関連のある項目が多く取り 上げら水ているのに対して，長い発病経過から生ずる disuse syndromes ${ }^{12}$ ) は評価項目に阻害因子として取り 上げられたのが少なかったためといえよう。一方，評価 項目の妥当性は,年齢因子, 発病経過々は無関係の阻害因 子も含めて判定基準の問題にある. 多くの評価項目は画 一的に判定され党るものではなく, 程度にいくつかの段 階をもうけなけれ代判定に困難をきたす場合がある．各 評価項目とも。判定基準を段階づけることにより，阻害因 
子として妥当性があるかどうか独立検定が可能をなり， より正確な評価法の確立が期待できるが, 判定基準の煩 わしさからは簡便さが失われてしまら。

杰た, 純医学的問題といえる内科的合併症は当然 risk 管理をはじめ, 回復に関与する大きな因子として取り上 げられるべきであるが，評価要素として他の阻害因子と 同一に標準化するには問題がある。それは表 9 から明ら かなように, 合併症の有無に問題があるのでなく, 合併症 の種類・重症度に問題があるからである.これは個々の 症例を検討することにより, 治療プログラムのオリエン テーションも明らかとなる. 症例 1 は, 高齢者であるう 光に 2 合併症があるため, 十分な回復は考えられなかっ たが，治療意欲が高かったため，障害を克服して回復し たとい方るし, 症例 2 は, 合併症はコントロールされて いるにかかわらず，心理的不安感・依存性が動機づけを 困難にして回復が不十分であったといえる.この 2 症例 のように, disability score, 合併症だけでは予後の判 定を的確に得られ楊合もある。われわれ臨床医は種々 の評洒法から得られる資料をもとに, 患者の現存の障害 度と予後を判定するが, physiatrist として個々の症例 経験を積むことにより，判定もより的確なものとなるで あろう。

\section{むすび}

身体障害者の能力の障害度を包括的にとらえる評価法 Disability Evaluation は単に現存の障害度を知るため だけでなく，早期に患者の社会的適応を決定するうえに も必要であり, リハビリテーション医学でも重要な課題 の一つである、それは純医学的のものから, 職業的リ八 ビリテーションに至るまで, 広い範囲の評価が 望まし い。しかし，わが国の現状として職業的分野はまだ手が とどかない. Disability Evaluation として, 職業的要 素を除いた神経学的, 整形外科的, 一精神医学・心理学 的, 社会・経済的の 4 要素について, 簡便な方法として 阻害因子を評価項目に取り上げてみた。評価項目の妥当 性については問題があったが, 入院時に和ける ADL 改
善のめやすとして利用価值があると思う。今後は評価項 目の独立検定が可能となるよう, 評価基準を段階つけた Disability Evaluation を確立してみたい。

本論交の一部要旨は昭和 43 年, 第 5 回 日本りハビリ テーション医学会総会で発表した。

（金久卓也教授のご指導・ご校閲感謝します.）

\section{文 献}

1) Ruilmann, C. J. : Rehabilitation potential of elderly patients, Tex. st. J. Med., 58, 636, 1962.

2) Nagi, S. Z. : A study in the evaluation of disability and rehabilitation potential, Amer. J. publ. Hlth., 54, 1968, 1964.

3) 上田敏：リハビリテーションの立場からみた運 動障害の分類と評価, 内科, 18, 889, 1966.

4) Moskowitz, E., et al. : Classification of disability in the chronically ill and aging, J. Chron. Dis. 5, 342, 1957.

5) Sokolow, J., et al. : Functional approach to disability evaluation, J.A.M.A., 167, 1575, 1958.

6) Kaplan, L. I., et al. : An approach to disability evaluation, Arch. phys. Med. \& Rehab., 41, 337, 1960.

7) Sokolow, J., et al. : A new approach to the objective evaluation of physical disability, J. chron. Dis., 15, 105, 1962.

8) 横山㦑: 在宅脳卒中後遺定者の実態, リハビリ テーション医学，4，118，1967.

9) 福井卖彦・他：脳卒中後麻瘦上肢の回復につい て, 第 4 回日本リハビリテーション医学会, 1967.

10）森園隆一・他: 片麻瘦上肢の, 用手機能検査（巧 維性評価)，リハビリテーション医学， $\mathbf{4}, 221$, 1967.

11) 森園隆一：片麻疩上肢の機能評価に関する研 究, 鹿大医誌, 20, 20, 1968.

12) Hirschberg, G. G., et al. : Rehabilitation, 1st ed., J. B. Lippincott Company, Philadelphia, 1964. 